\title{
Estimation of Green-Ampt effective hydraulic conductivity for rangelands
}

\author{
MARY R. KIDWELL, MARK A. WELTZ, AND D. PHILLIP GUERTIN
}

Authors are research assistant and hydrologist, USDA-ARS, Southwest Watershed Research Center, 2000 E. Allen Road, Tucson, Ariz. 85719; associate professor, School of Renewable Natural Resources, University of Ariz., Tucson, Ariz. 85721.

\begin{abstract}
Effective hydraulic conductivity $\left(K_{e}\right)$ is an important parameter for the prediction of infiltration and runoff volume from storms. The Water Erosion Prediction Project (WEPP) model, which uses a modified Green-Ampt equation, is sensitive to the hydraulic conductivity parameter in the prediction of runoff volume and peak discharge. Two sets of algorithms developed from cropland data to predict $K_{e}$ have previsouly been used in the WEPP model. When tested with data collected on rangelands, these equations resulted in low predictions of $K_{e}$ which significantly over-estimated runoff volume. The errors in runoff prediction were propagated through the model and resulted in poor predictions of peak discharge and sediment yield. The objective of this research was to develop a new predictive equation to calculate $K_{e}$ specifically for use on rangelands using field data collected in 8 western states on 15 different soil/vegetation complexes. A distinction was made between ground cover parameters located outside and underneath plant canopy in an effort to account for the significant spatial variability that occurs on most rangelands. Optimized $K_{e}$ values were determined using the WEPP model and observed runoff data. A regression model $\left(r^{2}=0.60\right)$ was then developed to predict $K_{e}$ using measured soil, canopy cover, and spatially distributed ground cover data from 44 plots. Independent rangeland data sets are now required to test the new equation to determine how well the relationships developed from the data used in this study extend to other rangeland areas.
\end{abstract}

Key Words: WEPP, infiltration, runoff, hydrologic modeling, spatial variability, ground cover

The Water Erosion Prediction Project (WEPP) model (Lane and Nearing 1989) was developed to provide process-based erosion prediction technology for croplands, rangelands, and forests to organizations involved in soil and water conservation and environmental assessment. To be successful in predicting erosion, the model must first succeed in predicting infiltration and surface runoff. The infiltration component of the WEPP model uses the Green-Ampt equation (Green and Ampt 1911) as modified by

The authors would like to thank all the members of the rangeland study team who collected the data used in this study including Leonard Lane, Jeff Stone Roger Simanton, Mariano Hernandez, Howard Larson, and the many other USDAARS staff and students involved in the project.

Manuscript accepted 12 May 1996.
Mein and Larson (1973) to obtain the time to ponding and infiltration rates for steady rainfall. This equation was further modified by Chu (1978) to simulate infiltration for unsteady rainfall events, allowing for alternating periods of ponded and unponded conditions.

Although this latest technology for modeling runoff and erosion represents a major improvement over older models, significant problems still exist as a result of the techniques used to estimate model parameters under rangeland conditions. This is particularly true in modeling infiltration. Estimates of hydraulic conductivity change with the scale of measurement as a result of the high spatial and temporal variability that cxists in natural systems (Dunne et al. 1991). Current methods for measuring hydraulic properties in the field are expensive and time consuming and therefore alternative techniques are needed to estimate model parameters and improve model results for rangelands.

The approach used in WEPP to simplify parameterization is to estimate hydraulic properties by relating them to soil and vegetation data that are commonly collected and readily available. The objectives of this research are to evaluate 2 existing sets of algorithms used in the WEPP model to predict effective hydraulic conductivity $\left(\mathrm{K}_{\mathrm{e}}\right)$ and to develop an alternative method. All 3 methods are compared to optimized $\mathrm{K}_{\mathrm{e}}$ parameters determined with the WEPP model.

\section{Infiltration Model Description}

\section{Green-Ampt Equation}

The form of the Green-Ampt equation used in WEPP to calculate the infiltration rate after ponding occurs is:

$$
\mathbf{f}=K_{\mathrm{e}}\left(1+\frac{N_{\mathrm{s}}}{F}\right)
$$

where $f$ is the infiltration rate $\left(\mathrm{mm} \mathrm{hr}^{-1}\right), \mathrm{K}_{\mathrm{e}}$ is effective saturated hydraulic conductivity (m sec${ }^{-1}$ ), $N_{s}$ is the effective capillary pressure head at the welling front ( $\mathrm{m}$ ), and $\mathrm{F}$ is the cumulative infiltration depth (m). Cumulative infiltration depth is calculated as:

$$
K_{e} t=F-N_{s} \text { in }\left(1+\frac{F}{N_{s}}\right) \quad\left(t>t_{p}\right)
$$

where $t$ is time $(\mathrm{sec})$ and $t_{p}$ is time to ponding (sec). Effective capillary pressure head at the wetting front is:

$$
N_{s}=\left(\eta_{\mathrm{e}}-\theta_{\mathrm{v}}\right)\left(\psi-h_{0}\right)
$$

where $\eta_{e}$ is field-saturated porosity $\left(\mathrm{m}^{3} \mathrm{~m}^{-3}\right), \theta_{v}$ is initial volu- 
metric water content $\left(\mathrm{m}^{3} \mathrm{~m}^{-3}\right), \psi$ is the average capillary pressure head across the wetting front $(\mathrm{m})$, and $h_{0}$ is the depth of ponding over the soil surface. The average capillary pressure head is estimated internally in WEPP as a function of soil properties (Rawls and Brakensiek 1983).

Prior to surface ponding the infiltration rate is equal to the rainfall rate and cumulative infiltration is equal to cumulative rainfall. The infiltration rate starts to decline when ponding begins, decreasing as the depth of wetted soil increases. If rainfall continues for a sufficient period, infiltration generally approaches a final, constant, steady rate.

For this study, volumetric water content was calculated as:

$$
\theta_{\mathrm{v}}=\mathrm{w} \rho_{\mathrm{b}} \rho_{\mathrm{w}}{ }^{-1}
$$

where $w$ is initial soil water content by weight $\left(\mathrm{g} \mathrm{g} \mathrm{g}^{-1}\right), \rho_{\mathrm{b}}$ is dry bulk density $\left(\mathrm{gm} \mathrm{cm}^{-3}\right)$, and $\rho_{\mathrm{w}}$ is the density of water (about 1 $\mathrm{gm} \mathrm{cm}^{-3}$ ). Effective field-saturated porosity was calculated as:

$$
\eta_{\mathrm{e}}=0.9\left(1-\rho_{\mathrm{b}} \rho_{\mathrm{s}}^{-1}\right)
$$

where $\rho_{\mathrm{s}}$ is soil particle density, and is typically $2.65 \mathrm{gm} \mathrm{cm}^{-3}$ for a mineral soil.

\section{Parameter Estimation}

The importance of hydraulic conductivity in the calculation of infiltration with the Green-Ampt equation has been well documented. Brakensiek and Onstad (1977) found that the effective conductivity parameters have a major influence on infiltration and runoff amounts and rates. Moore (1981) showed that both the rate and amount of infiltration are more sensitive to hydraulic conductivity and available porosity than to the wetting front capillary potential. Tiscareno-Lopez et al. (1993) concluded that both the runoff volume and peak runoff rate computed by the WEPP model are very sensitive to the hydraulic conductivity parameters in the Green-Ampt equation.

One approach to estimating Green-Ampt hydraulic conductivity is to use an average or effective value, thus ignoring the variable and random nature of the physical processes. Green-Ampt effective hydraulic conductivity $\left(\mathrm{K}_{\mathrm{e}}\right)$ is a lumped parameter that integrates a soil's ability to infiltrate water under variable soil pore structure, surface microtopography, and rainfall amount and intensity distributions. The $\mathrm{K}_{\mathrm{e}}$ value derived in this study provides a single integrated value to represent an entire plot.

Most research to date has focused on saturated hydraulic conductivity $\left(\mathrm{K}_{\mathrm{s}}\right)$, the ability of a soil to transmit water under fully saturated conditions (Klute and Dirksen 1986), rather than $K_{e}$, because it is comparatively easy to measure under laboratory and field conditions. One approach consists of correlating hydraulic conductivity with easily measurable soil properties such as soil texture, effective porosity, bulk density, and coarse fragments in the soil.

Rawls and Brakensiek (1989) evaluated a number of physical factors that are important in the estimation of $\mathrm{K}_{\mathrm{s}}$. Their findings were incorporated in the algorithms used to calculate $\mathrm{K}_{\mathrm{e}}$ in early versions of WEPP (Rawls et al. 1989). This was accomplished by adjusting $\mathrm{K}_{\mathrm{s}}$ to account for the weight of coarse rock fragments in the soil, frozen soil, soil crusting, soil macroporosity, and soil cover, using the following equation:

$$
\begin{aligned}
K_{e}= & K_{b}\left[C_{f}\left[\left(\left(B_{c} A_{c}^{-1}\right) C_{r}\right)+M_{f}\left(\left(1-B_{c}\right) A_{c}^{-1}\right)\right]+\right. \\
& \left.\left(B_{o} A_{c}^{-1}\right) C_{r}+M_{f}\left(\left(1-B_{o}\right) A_{o}^{-1}\right)\right]
\end{aligned}
$$

where $K_{b}$ is baseline hydraulic conductivity $\left(\mathrm{m} \mathrm{sec}^{-1}\right), C_{f}$ is a canopy correction factor (fraction), $\mathrm{B}_{\mathrm{c}}$ is bare area under canopy (fraction), $A_{c}$ is total canopy area (fraction), $B_{0}$ is bare area outside canopy (fraction), $A_{o}$ is total area outside canopy (fraction), $\mathrm{C}_{\mathrm{r}}$ is a crust reduction factor (unitless), and $\mathrm{M}_{\mathrm{f}}$ is a macroporosity factor $\left(\mathrm{m} \mathrm{m}^{-1}\right), \mathrm{C}_{\mathrm{r}}$ is calculated as a function of the average wetting front depth, soil crust thickness, a correction factor for partial saturation of the subcrust soil, and a crust factor. $\mathbf{M}_{\mathrm{f}}$ is computed as a function of sand and clay content. The equations used to calculate these variables were developed by Brakensiek and Rawls (1983) for plowed agricultural soils with a constant crust thickness of $0.005 \mathrm{~m}$.

Baseline hydraulic conductivity is given by (Rawls et al. 1989):

$$
K_{b}=K_{s}\left(1-M_{c f}\right) F S_{a}
$$

where $K_{\mathrm{s}}$ is saturated hydraulic conductivity $\left(\mathrm{m} \mathrm{sec}^{-1}\right.$ ), $\mathrm{M}_{\mathrm{cf}}$ is the fraction of course fragments in the soil, and $\mathrm{FS}_{\mathrm{a}}$ is a frozen soil factor (unitless). The equation used to calculate $\mathrm{K}_{\mathrm{s}}$ was developed from an extensive agricultural soils database (Rawls and Brakensiek 1985) and is:

$$
K_{s}=Q k\left[\left(1-Q_{t}\right)^{2}\left(0.001 p_{t} O_{r}^{-1}\right)^{2} 0.00020 C^{2}\right]^{-1}
$$

where $Q_{e}$ is effective soil porosity $\left(\mathrm{m}^{3} \mathrm{~m}^{-3}\right), Q_{t}$ is total soil porosity $\left(\mathrm{m}^{3} \mathrm{~m}^{-3}\right), \mathrm{p}_{\mathrm{t}}$ is soil bulk density $\left(\mathrm{mg} \mathrm{m}^{-3}\right), \mathrm{O}_{\mathrm{r}}$ is soil water content $\left(\mathrm{m}^{3} \mathrm{~m}^{-3}\right)$, and $\mathrm{C}$ is an adjustment factor for soil texture (unitless).

The approach outlined above is complex and involves several levels of nested regression equations. In some cases the parameters overlap and thus an error at 1 level can be propagated through to the final prediction of $\mathrm{K}_{\mathrm{e}}$. Wilcox et al. (1992) reported a poor corrclation between predicted and observed runoff using these empirical equations with rangeland data from rainfall simulation experiments conducted in southwestern Idaho. Savabi et al. (1995) reported that WEPP underestimated runoff from naturally vegetated plots in Texas using the Rawls equation for estimating $\mathrm{K}_{\mathrm{s}}$ (Eq. 8).

In subsequent versions of the WEPP model, a different set of algorithms replaced $\mathrm{Eq}$. 6 for predicting $\mathrm{K}_{\mathrm{e}}$. With these algorithms, developed by Risse et al. (1995), $\mathrm{K}_{\mathrm{e}}$ is calculated directly from basic soil properties. They are based on WEPP model optimization runs of both measured and curve number predicted runoff quantities on agricultural soils. A number of soil properties including sand, clay, silt, very fine sand, field capacity, wilting point, organic matter, CEC, and rock fragments were investigated through regression analysis to determine which could best be used in the prediction of $\mathrm{K}_{\mathrm{e}}$.

For soils with a clay content less than or equal to $40 \%, \mathrm{~K}_{\mathrm{e}}$ is calculated as:

$$
K_{e}=-0.46+0.05 S a^{1.25}+9.44 C E C^{0.69}
$$

where $\mathrm{Sa}$ is percent sand and CEC is the cation exchange capacity (meq/100g of soil) in the surface soil layer. If the cation exchange capacity is less than or equal to $1.0, \mathrm{~K}_{\mathrm{e}}$ is:

$$
K_{e}=8.98+0.05 \mathrm{Sa}^{1.25}
$$

If clay content is greater than $40 \%, \mathrm{~K}_{\mathrm{e}}$ is given by:

$$
K_{e}=-0.016 \mathrm{e}^{171 \mathrm{Cl}^{-1}}
$$

where $\mathrm{Cl}$ is percent clay in the surface soil layer.

The combination of equations outlined above resulted in an $r^{2}$ of 0.78 for the test data set which was comprised of 43 different soil series. The selected equations were chosen as a result of their simplicity and the standard error of their estimates. 


\section{Materials and Methods}

\section{Study Sites}

Field data collected during the 1987 and 1988 USDA WEPP rangeland field study from 15 sites with a total of 44 plots in the Western and Great Plains regions of the United States (Simanton et al. 1987 ; 1991) were used for the research described in this paper. Abiotic and biotic descriptive data for each site are presented in Tables 1 and 2.

\section{Experimental Design and Sampling Methods}

Simulated rainfall was applied to undisturbed, paired plots measuring 3.05 by 10.67 meters using a rotating boom simulator developed by Swanson (1965). Plots were located in the same soil and vegetation type at each site. Rainfall simulations were made on each plot representing dry and wet antecedent moisture conditions. During the dry run, water was applied at a rate of 60 $\mathrm{mm} \mathrm{hr}^{-1}$ for 1 hour. The wet run was made 24 hours later at a rate of $60 \mathrm{~mm} \mathrm{hr}^{-1}$ for 30 minutes.

Total rainfall amount and distribution were measured with 6 non-recording raingages positioned around each plot. Rainfall intensity was measured with a recording raingage located between the paired plots. Runoff passed through a pre-calibrated supercritical flume at the downslope end of each plot, flow depths were measured with a pressure transducer bubble gage, and continuous hydrographs were developed using the flume's depth/discharge rating table (Simanton et al. 1987).

A major objective of vegetation data collection was to provide an estimate of spatial distribution of canopy and ground surface cover. Measured ground cover characteristics were bare soil, rock (mineral particles greater than $2 \mathrm{~mm}$ ), litter (organic material in direct contact with the soil surface), cryptogams (algae, moss and lichens), and plant hasal cover. Vegetation composition (i.e. grass, shrub, forb, cactus), canopy cover, ground surface characteristics, and surface roughness were measured before rainfall simulation using a 49-pin point frame placed perpendicular to the plot slope at 10 evenly spaced transects along the plot border. A steel pin was lowered vertically at $5 \mathrm{~cm}$ intervals along the point frame. If the pin touched a plant aerial part, the lifeform was recorded. The pin was then lowered to the plot surface and the first characteristic touched was recorded for that point for determination of ground cover. It is often difficult to determine where canopy cover ends and plant basal area begins for areas that have been heavily grazed, for many prostrate growth form plant types, and on sites with high surface roughness and pedestalled plants. For this work, canopy cover is defined as any plant part elevated $2.5 \mathrm{~cm}$ or more from the soil surface. A plant part in contact with the pinpoint within $2.5 \mathrm{~cm}$ of the soil surface is considered to be basal cover.

Areas located directly underneath plant canopy are referred to as under-canopy areas while areas located between plants (i.e. no canopy cover directly above) are referred to as interspace areas (Fig. 1a). Total under-canopy ground cover is calculated as the sum of the fraction of each ground cover component located under vegetative canopy (as defined above), while total interspace cover is calculated as the sum of the fraction of each ground cover component located outside of plant canopy. For example, if $30 \%$ of a plot is covered by rocks, and $40 \%$ of those rocks are in interspace areas while $60 \%$ are under-canopy, then total rock cover in the interspaces is $12 \%\{(40 \times 30) / 100\}$. Similarly, total rock cover under-canopy is $18 \%\{(60 \times 30) / 100\}$. Distributions of litter, basal vegetation, and cryptogams are similarly calculated. Total interspace and under-canopy area are calculated by summing the cover for the individual components located in their respective areas. Plant nomenclature used throughout the discussion follows Gould (1975).

\section{Model Configuration and Optimization}

Measured topographic, precipitation, vegetation and soils data from the WEPP rangeland field study were used to run the WEPP model for a single rainfall event. Topographic data included plot length, width, and slope values. Measured precipitation data con-

Table 1. Ablotic site characteristics from the WEPP rangeland field experiments.

\begin{tabular}{|c|c|c|c|c|c|c|}
\hline & Site & Soil Family & $\begin{array}{c}\text { Soil } \\
\text { series }\end{array}$ & $\begin{array}{l}\text { Surface } \\
\text { texture }\end{array}$ & Slope & Elevation \\
\hline & & & & & $(\%)$ & (m) \\
\hline 1) & Tombstone, Ariz. & Ustochreptic calciorthid & Stronghold & Sandy loam & 10 & 1,377 \\
\hline 2) & Tombstone, Ariz. & Ustollic haplargid & Forest & Sandy clay loam & 4 & 1,420 \\
\hline 3) & Susanville, Calif. & Typic argixeroll & Jauriga & Sandy loam & 13 & 1,769 \\
\hline 4) & Susanville, Calif. & Typic argixeroll & Jauriga & Sandy loam & 13 & 1,769 \\
\hline 5) & Meeker, Colo. & Typic camborthid & Degater & Silty clay & 10 & 1,760 \\
\hline 6) & Sidney, Mont. & Typic argiboroll & Vida & I oam & 10 & $\mathrm{~N} / \mathrm{A}$ \\
\hline 7) & Los Alamos, N.M. & Aridic haplustalf & Hackroy & Sandy loam & 7 & 2,144 \\
\hline 8) & Cuba, N.M. & Ustollic camborthid & Querencia & Sandy loam & 7 & 1,928 \\
\hline 9) & Chickasha, Okla. & Udic argiustoll & Grant & Loam & 5 & 378 \\
\hline 10) & Chickasha, Okla. & Udic arguistoll & Grant & Sandy loam ${ }^{1}$ & 5 & 369 \\
\hline 11) & Woodward, Okla. & Typic ustochrept & Quinlan & Loam & 6 & 615 \\
\hline 12) & Freedom, Okla. & Typic ustochrept & Woodward & Loam & 6 & 553 \\
\hline 13) & Cottonwood, S.Dak. & Typic torrert & Pierre & Clay & 8 & 744 \\
\hline 14) & Cottonwood, S. Dak. & Typic torrert & Pierre & Clay & 12 & 744 \\
\hline 15) & Sonora, Tex. & Thermic calciustoll & Perves & Cobbly clay & 8 & 650 \\
\hline
\end{tabular}

'Farm land abandoned during the 1930 's that had returned to rangeland. The majority of the 'A' horizon had been previously eroded. 
Table 2. Biotic mean site characteristics from the WEPP rangeland field experiments.

\begin{tabular}{|c|c|c|c|c|c|c|c|}
\hline & Site & Rangeland cover type $^{1}$ & $\begin{array}{l}\text { Range } \\
\text { site }\end{array}$ & $\begin{array}{l}\text { Ecological } \\
\text { status }^{2}\end{array}$ & & Cover & $\begin{array}{l}\text { Standing } \\
\text { Biomass }\end{array}$ \\
\hline & & & & & Canopy & Ground & $\left(\mathrm{kg} \mathrm{ha}^{-1}\right)$ \\
\hline 2) & Tombstone, Ariz. & Grama-Tobosa-Shrub & Loamy upland & 55 & 18 & 40 & 752 \\
\hline 3) & Susanville, Calif. & Basin Big Brush & Loamy & 55 & 29 & 84 & 5,743 \\
\hline 6) & Sidney, Mont. & $\begin{array}{c}\text { Wheatgrass-Grama- } \\
\text { Needlegrass }\end{array}$ & Silty & 58 & 12 & 81 & 2,141 \\
\hline 7) & Los Alamos, N.M. & $\begin{array}{l}\text { Juniper-Pinyon } \\
\text { Woodland }\end{array}$ & $\begin{array}{l}\text { Woodland } \\
\text { community }\end{array}$ & $\mathrm{NA}^{3}$ & 16 & 72 & 1,382 \\
\hline 8) & Cuba, N.M. & Blue grama-Galleta & I namy & 47 & 13 & 62 & 817 \\
\hline 11) & Woodward, Okla. & Bluestem-Grama & Shallow prairie & 28 & 45 & 62 & 1,505 \\
\hline 12) & Freedom, Okla. & Bluestem prairie & Loamy prairie & 30 & 39 & 72 & 1,223 \\
\hline 13) & Cottonwood, S.Dak. & $\begin{array}{l}\text { Wheatgrass- } \\
\text { Needlegrass }\end{array}$ & $\begin{array}{l}\text { Clayey west } \\
\text { central }\end{array}$ & 100 & 46 & 68 & 2,049 \\
\hline 14) & Cottonwood, S.Dak. & $\begin{array}{c}\text { Blue grama } \\
\text { Buffalograsse }\end{array}$ & $\begin{array}{l}\text { Clayey west } \\
\text { central }\end{array}$ & 30 & 34 & 81 & 529 \\
\hline 15) & Sonora, Tex. & Juniper-Oak & Shallow & 35 & 39 & 68 & 2,461 \\
\hline
\end{tabular}

${ }_{1}^{1}$ Shiflet (1994).

${ }^{2}$ Ecological status is a similarity index that expresses the degree to which the composition of the present plant community is a reflection of the historic climax plant community. This similarity index may be used with other site criterion or characteristics to determine rangeland health. Four classes are used to express the percentage of the historic climax plant community on the site: I 76-100; II 51-75; III 26-50; IV 0-25 (USDA, National Resources Conservation Service (1995).

${ }^{3} \mathrm{NA}$ - Ecological status indices are not appropriate for woodland and annual grassland communities.

sisted of rainfall volume, intensity, and duration. Values used to characterize vegetation included total ground cover by each component, their distributions between interspace and under-canopy areas, and total canopy cover. Complete soil pedon descriptions, sampling, and analysis were made by the USDA-Natural Resource Conservation Service (NRCS) Soil Survey Laboratory at each of the rangeland sites as a part of the WEPP Rangeland Field Study. Measured values of sand, clay, organic matter, bulk density and cation exchange capacity from the surface horizon from a single pedon were used. The same values determined from 1 pedon were used to define the soil parameters for all plots at a particular site.

The rainfall simulation plots were prewet with $60 \mathrm{~mm}$ of water and allowed to drain for 24 hours to minimize antecedent soil water content differences. Soil water content was measured at 3 locations on the plot: top, middle, and bottom before the rainfall simulation runs. Soil water content was at or near field capacity for all sites. Saturation by volume was calculated using the following equation (Hillel 1980):

$$
s=\theta_{\mathrm{v}} \eta_{\mathrm{e}}^{-1}
$$

where $s$ is the degree of saturation by volume, $\theta_{\mathrm{v}}$ is the volumetric water content, and $\eta_{e}$ is effective soil porosity.

The WEPP model was used to generate an optimized $\mathrm{K}_{e}$ value and a corresponding predicted runoff value for each of the 44 plots in the data set under a single storm simulation using data from the wet run. The model was run for a range of values of $\mathrm{K}_{e}$ for each plot, and corresponding model predicted runoff volume was generated. An optimization program, based on a least squares analysis, was used to interpolate between 2 values of $\mathrm{K}_{\mathrm{e}}$ until the best fit was found.

\section{Data Analysis}

Data from the WEPP field studies were used to evaluate Eq. 6 (Rawls et al. 1989) and Eqs. 9-11 (Risse et al. 1995). $\mathrm{K}_{\mathrm{e}}$ values were calculated with both equations and compared with the optimized $\mathrm{K}_{\mathrm{e}}$ values for each plot. The WEPP model was used to generate runoff volume for both sets of predicted $\mathrm{K}_{\mathrm{e}}$ values. Predicted runoff volume corresponding to each set of predicted $\mathrm{K}_{\mathrm{e}}$ values was then compared with observed runoff volume.

A regression equation was developed and tested using measured soil and cover data from all of the plots. Maximum $\mathbf{r}^{2}$ regression analysis was used to generate regression equations within an $85 \%$ confidence range for the dependent variable (optimized $K_{e}$ ). The soil parameters included in the analysis were percent sand, silt, and clay, cation exchange capacity (meq $100 \mathrm{~g}^{-1}$ soil), bulk density $\left(\mathrm{g} \mathrm{cm}^{-3}\right)$, and organic matter (percent by volume). The components of ground cover that were evaluated include basal vegetation, litter (plant residue), rock, and cryptogams. Both the total cover values 
where $\mathrm{C} 1$ is clay content (fraction), $\mathrm{L}_{\mathrm{r}}$ is litter cover in interspace areas (fraction), $B_{r}$ is basal cover in interspace areas (fraction), and $R_{i}$ is rock cover in under-canopy areas (fraction). As with all equations developed with regression analysis, Eq. 13 should only be used within the spread of the data that were used to derive it or unreasonable results may be obtained. From a physical standpoint, the independence of the 4 terms is an attractive feature of the equation.

Correlation coefficients for each variable used in the multiple regression analysis were calculated. Of all the terms tested, clay

Table 3. Observed runoff volume and optimized hydraulic conductivity $\left(K_{e}\right)$ from the WEPP rangeland field experiements.

(b)

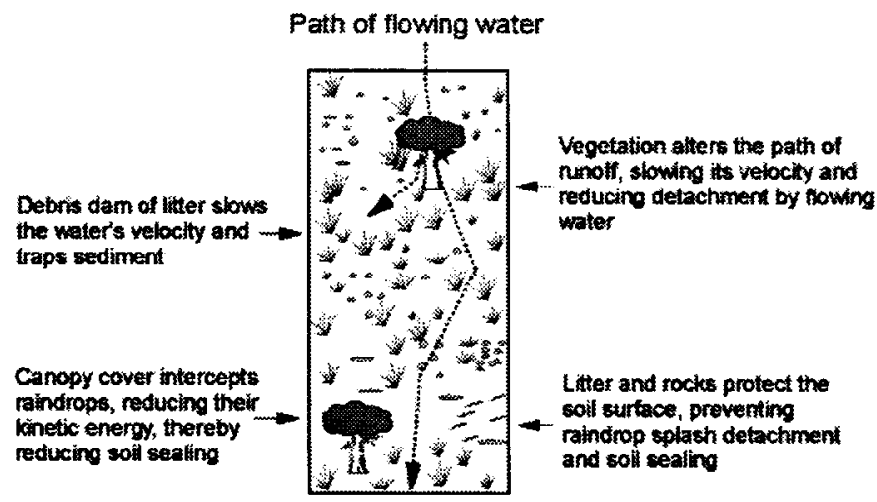

\begin{tabular}{|c|c|c|c|c|c|}
\hline & Site & Plot & Year & $\begin{array}{c}\text { Observed } \\
\text { Runoff }\end{array}$ & $\begin{array}{c}\text { Optimized } \\
\mathrm{K}_{\mathrm{e}}\end{array}$ \\
\hline & & & & $(\mathrm{mm})$ & $\left(\mathrm{mm} \mathrm{hr}^{-1}\right)$ \\
\hline \multirow[t]{2}{*}{ 1) } & Tombstone, Ariz. & 33 & 87 & 1.5 & 24.5 \\
\hline & & 36 & 87 & 2.5 & 32.9 \\
\hline \multirow[t]{2}{*}{ 2) } & Tombstone, Ariz. & 52 & 87 & 12.8 & 13.8 \\
\hline & & 54 & 87 & 16.2 & 3.6 \\
\hline \multirow[t]{4}{*}{ 3) } & Susanville, Calif. & 137 & 87 & 0.4 & 15.3 \\
\hline & & 140 & 87 & 0.2 & 15.9 \\
\hline & & 137 & 88 & 0.1 & 17.0 \\
\hline & & 140 & 88 & 0.8 & 18.7 \\
\hline \multirow[t]{6}{*}{ 4) } & Susanville, Calif. & 141 & 87 & 0.4 & 13.8 \\
\hline & & 142 & 87 & 0.2 & 15.4 \\
\hline & & 143 & 87 & 1.0 & 20.1 \\
\hline & & 144 & 87 & 2.0 & 15.3 \\
\hline & & 143 & 88 & 2.0 & 18.4 \\
\hline & & 144 & 88 & 2.0 & 20.3 \\
\hline \multirow[t]{2}{*}{ 5) } & Meeker, Colo. & 107 & 87 & 1.5 & 10.8 \\
\hline & & 112 & 87 & 4.6 & 5.2 \\
\hline \multirow[t]{2}{*}{ 6) } & Sidney, Mont. & 103 & 87 & 1.0 & 26.5 \\
\hline & & 106 & 87 & 0.3 & 18.4 \\
\hline \multirow[t]{2}{*}{ 7) } & Los Alamos, N.M. & 128 & 87 & 8.1 & 5.2 \\
\hline & & 129 & 87 & 8.8 & 7.3 \\
\hline \multirow[t]{2}{*}{ 8) } & Cuba, N.M. & 132 & 87 & 4.5 & 14.5 \\
\hline & & 133 & 87 & 1.3 & 18.5 \\
\hline \multirow[t]{4}{*}{ 9) } & Chickasha, Okla. & 71 & 87 & 17.0 & 9.4 \\
\hline & & 76 & 87 & 11.5 & 11.5 \\
\hline & & 71 & 88 & 5.6 & 22.7 \\
\hline & & 76 & 88 & 0.6 & 27.7 \\
\hline \multirow[t]{4}{*}{ 10) } & Chickasha, Okla. & 77 & 87 & 11.6 & 10.4 \\
\hline & & 80 & 87 & 10.7 & 8.8 \\
\hline & & 77 & 88 & 6.6 & 18.8 \\
\hline & & 80 & 88 & 6.3 & 16.5 \\
\hline \multirow[t]{4}{*}{ 11) } & Woodward, Okla. & 91 & 87 & 0.2 & 25.9 \\
\hline & & 94 & 87 & 3.3 & 15.5 \\
\hline & & 91 & 88 & 0.6 & 18.2 \\
\hline & & 94 & 88 & 1.9 & 22.0 \\
\hline \multirow[t]{2}{*}{ 12) } & Freedom, Okla. & 156 & 88 & 1.5 & 16.8 \\
\hline & & 158 & 88 & 3.0 & 13.0 \\
\hline \multirow[t]{2}{*}{ 13) } & Cottonwood, S. Dak. & 113 & 88 & 1.5 & 10.0 \\
\hline & & 118 & 88 & 3.0 & 8.6 \\
\hline \multirow[t]{4}{*}{ 14) } & Cottonwood, S. Dak. & 119 & 87 & 5.0 & 4.2 \\
\hline & & 122 & 87 & 7.6 & 3.0 \\
\hline & & 119 & 88 & 8.5 & 2.7 \\
\hline & & 122 & 88 & 6.8 & 4.4 \\
\hline \multirow[t]{2}{*}{ 15) } & Sonora, Tex. & 67 & 87 & 16.5 & 0.8 \\
\hline & & 70 & 87 & 6.9 & 3.7 \\
\hline
\end{tabular}

The USDA neither guarantees nor warrants the standard of the product, and the use of the name by the USDA implies no approval of the product to the exclusion of others that may also be suitable. 
content was shown to have the strongest relationship with $\mathrm{K}_{\mathrm{e}}$ with a moderate ncgative correlation $(R=-0.53)$ at the $95 \%$ significance level. Conversely, sand content showed a moderate positive correlation $(R=0.48)$. It has been documented that soil texture is related to hydraulic conductivity on homogeneous soils, with increased sand content associated with increased conductivity (Rawls et al. 1982). In semiarid watersheds in Nevada, Blackburn (1975) found a significant relationship between infiltration rates and soil texture. He reported negative correlations between clay and silt-sized particles and infiltration, and a positive correlation between sand and infiltration.
Litter cover in interspace areas is represented by a positive term in Eq. 13, indicating that $\mathrm{K}_{\mathrm{e}}$ increases as litter cover in the interspaces increases. Litter cover in interspace areas ranged from 2.6 to $61.4 \%$ on the 44 plots evaluated, and in general was the most prevalent ground cover type (Table 4). Litter has long been recognized as effective in reducing soil erosion on rangelands (Singer et al. 1981, Khan et al. 1988, and Meyer et al. 1970). Litter cover at the soil surface intercepts raindrops and dissipates their energy (Fig. Ib). This reduces the clogging of soil pores with sediment, reducing sealing and crusting, thus enabling more infiltration. Litter cover also increases potential for debris dam

Table 4. Spatial cover data (\%) from the WEPP rangeland field experiments.

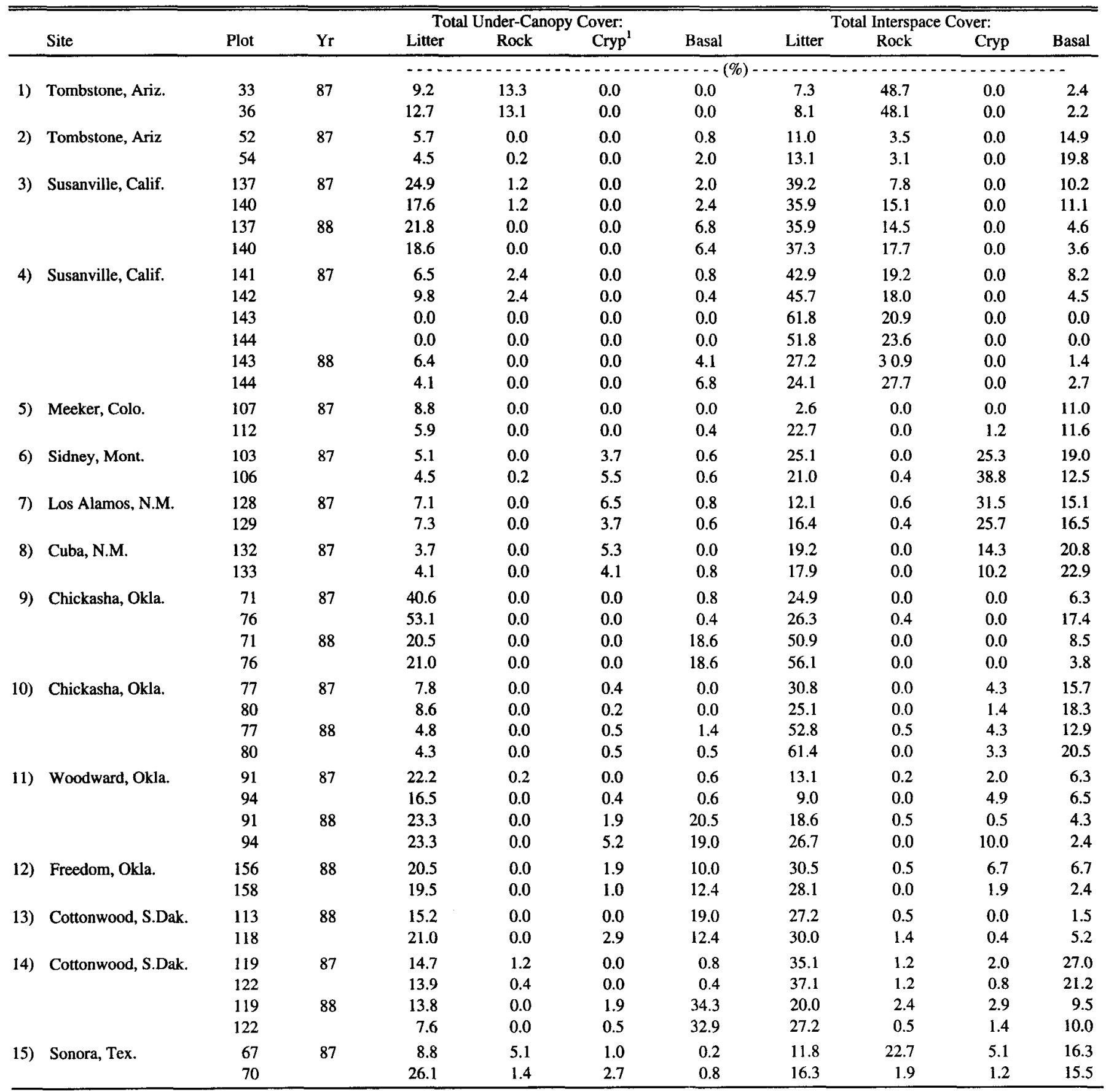

${ }^{1}$ Cryp is cryptogams, defined here as all moss, lichens, and algae. 


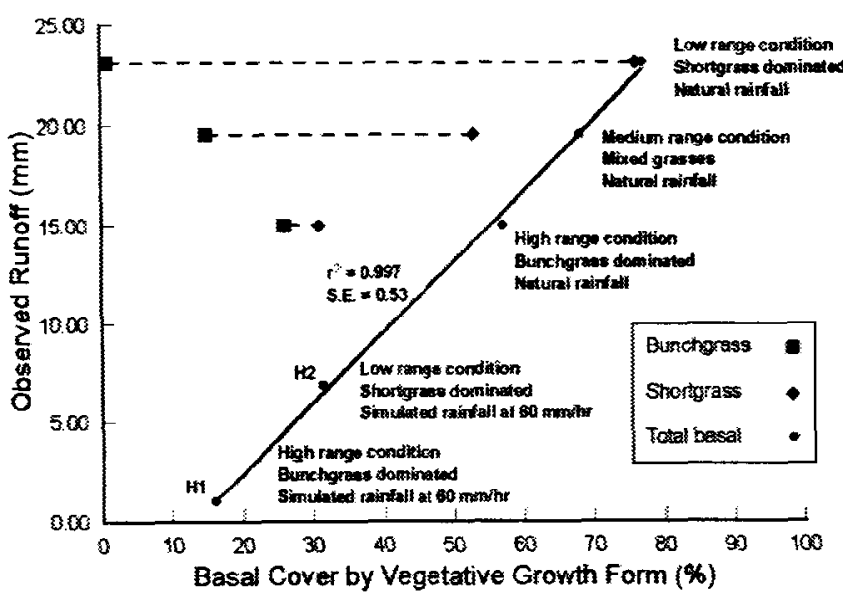

Fig. 2. Mean annual runoff plotted against basal cover by vegetative growth form (short grasses and bunch grasses) based on a study by Hanson et al. (1978). As represented by the dashed line, bunchgrass and shortgrass basal cover sum to give the total basal cover for each of the 3 watersheds (low, medium, and high range conditions). Also plotted are observed runoff vs. mean total basal cover from rainfall simulations conducted by the WEPP rangeland study team (Simanton et al. $1987 ; 1991$ ) within the low and high range condition watersheds evaluated by Hanson et al. (1978).

formation, providing an obstacle to the flow of water. The result is increased tortuosity and hydraulic roughness which reduces runoff velocity, increasing ponding and infiltration.

Vegetal cover is generally positively correlated to infiltration and negatively correlated to interrill erosion, whereas bare soil is generally associated with a decrease in infiltration (Packer 1951, Dadkhah and Gifford 1980). Many researchers have found higher infiltration rates under plant canopies than in the interspaces (Wood and Blackburn 1981, Thurow et al. 1986, and Tromble et al. 1974). Canopy cover tends to provide protection from raindrop impact, preventing the formation of a soil crust and dislodged soil particles from clogging soil pores, but all plants do not have the same impact in influencing infiltration rates.

In this study, basal cover in the interspace was found to be negatively correlated to $\mathrm{K}_{\mathrm{e}}$ and correlation analysis revealed a moderate negative relationship between the $2(R=-0.48)$. This relationship appears contrary to much of the previous hydrologic work in which increases in plant cover were related to decreases in runoff and increases in the apparent infiltration rate. However, the relation between plant community parameters (e.g., basal cover) and hydrologic response of uplands is a complex function that changes depending on the type of plant community being evaluated. Within a plant community, where the vegetative growth form remains constant and only the density of plants changes, the literature consistently indicates that infiltration rate increases as canopy cover increases (Packer 1951, Dadkhah and Gifford 1980). When the vegetative growth form shifts (e.g., from bunchgrass to shortgrass, or woodland to grassland), the relationship between basal and canopy cover and infiltration and runoff appears to shift. That is, equal amounts of vegetative cover within each of the different plant communities do not necessarily have the same relationship to apparent infiltration rates and runoff.

Hanson et al. (1978) initiated a ten-year study of hydrologic response as a function of grazing intensity at Cottonwood, South
Dakota. They constructed 4 watersheds ( 0.9 ha each) in 3 different pastures representing low, medium, and high range condition for a total of 12 watersheds. The low condition pasture was dominated by shortgrasses such as Bouteloul gracilis (H.B.K.) Lag. (blue grama) and Buchloe dactyloides (Nutt.) Engelm. (buffalograss). The high condition pasture was dominated by bunchgrasses including Agropyron smithii (Rydb.) (western wheatgrass) and Stipa viridula (Trin.) (green needlegrass). The fair pasture had a mixture of all 4 grass species. The authors reported that total annual runoff and runoff from summer convective storms increased as basal area increased from the bunchgrass-dominated pasture to the shortgrass-dominated pasture (Fig. 2). Our data from the Cottonwood research station shows similar results. The shortgrass-dominated community has a lower apparent infiltration rate than the bunchgrass-dominated site for both years they were evaluated. All 3 of these watersheds are located on a Pierre clay soil and no significant differences were found in bulk density, cation exchange capacity, organic matter, or depth of the A horizon. The main differences between the sites are in the type of plant species and the amount of plant biomass present.

Other researchers have reported that changes in vegetative growth form or plant species result in changes in the relationship between plant attributes of cover and basal area and apparent infiltration rates and runoff. Thurow et al. (1986) reported that areas dominated by bunchgrass species had greater infiltration rates than shortgrass dominated areas in the Edwards Plateau area in Texas. Rauzi et al. (1968) reported that infiltration rates and runoff were correlated to plant community type with mid and tall grass plant communities having higher infiltration rates and lower runoff rates than shortgrass plant communities using data from the northern and southern Great Plains regions. Thomas and Young (1954) found Hilaria mutica (Buckl.) Benth. (tobosa) sites had higher infiltration rates than did Buchloe dactyloides (Nutt.) Engelm. (buffalograss) sites. Weltz and Wood (1986) reported that Muhlenbergia richardsonis [Trin.] Rydh. (mat muhly) dominated sites had higher infiltration rates than Bouteloua gracilis (H.B.K.) Lag. (blue grama) dominated sites at Ft. Stanton, N. M.

The plants that dominated the interspaces in this study were small annual forbs and grasses. The highest total interspace cover by basal vegetation for any plot in this data set was only $27 \%$, and most plots had less than $20 \%$ cover (Table 4 ). The exact mechanism for the reduction of infiltration associated with these plants is not fully understand. It has been hypothesized that the reduction in infiltration rate is a function of increased bulk density, reduced organic matter content of the soil, or the difference in root distribution and biomass between short, mixed, and tall grass species. Root biomass in the top $10 \mathrm{~cm}$ of the soil was negatively correlated to $K_{e}$ in this study $(R=-0.47)$. Short grasses tend to have a more lateral, matted root structure as compared to the deeper reaching roots of the mid and tall grasses, resulting in differences in soil pore structure (Weaver and Harmon 1935). These differences might affect the ability of water to infiltrate the soil, resulting in increased runoff from shortgrass dominated sites. Although root biomass is not a term in Eq. 13, it has a similar negative relationship to $\mathrm{K}_{\mathrm{e}}$ to that of basal area. We hypothesize that basal cover may be a surrogate for addressing the variability of soil pore orientation and structure resulting from the lateral root orientation associated with short grass species.

Blackburn et al. (1992) reported that vegetative growth form (e.g., shrub, bunchgrass, sodgrass) is one of the primary factors influencing the spatial and temporal variability of surface soil 
processes that control infiltration on rangelands. To improve our ability to predict infiltration and runoff for these systems, we must first recognize that they are spatially and temporally influenced by growth form, amount, and distribution of native vegetation. Before predictive models can provide realistic estimates of the influence of alternative land management practices on infiltration and runoff they must be able to account for vegetationinduced spatial and temporal variability of soil surface factors. To accomplish this, new techniques are needed to develop better infiltration equations and parameters that address the inherent variability that exists on native and managed rangeland ecosystems, and additional research is required to develop a better understanding of the relationship between plant species and the infiltration process.

Cooke and Warren (1973) proposed that in a semiarid environment, as vegetal cover decreases, if rocks are present in the soil, rock cover should increase as a result of the removal of fine particles by raindrop impact and overland flow, leaving the coarse particles behind. This relationship is seen in the data in this study. Correlation analysis revealed a moderate negative relationship between basal cover and rock cover $(R=-0.57)$. The negative relationship found between basal cover in the interspaces and $\mathrm{K}_{e}$ could, therefore, be a secondary effect of low or no rock cover on those plots.

Rock cover under plant canopy is also positively related to $\mathrm{K}_{\mathrm{e}}$ in Eq. 13, and correlation analysis revealed a moderate positive relationship ( $R=0.31$ ). Only 13 of the 44 plots had any rock cover under plant canopy, however, and in most cases the percentage of such cover was very small (Table 4). Rock cover outside of plant canopy was present on 30 of the plots, and the percentage of rock cover on these plots was higher than that under plant canopy, in general, particularly on the shrub sites. Interspace rock cover and total rock cover were also positively correlated to $\mathrm{K}_{\mathrm{e}}(\mathrm{R}=0.38$ for both terms), suggesting that the location of the cover is less important than the actual absence or presence of rock cover itself.

The literature on the relationship between rock cover and infiltration and erosion is contradictory. A number of investigators have reported a negative relationship between rock cover and infiltration (Tromble et al. 1974, Abrahams and Parsons 1991, Brakensiek et al. 1986, Haupt 1967, Wilcox et al. 1988), while others have found a positive relationship (Lane et al. 1987, Simanton et al. 1984, Meyer et al. 1970). These contradictory results could be explained by the position of rock fragments in relation to the soil surface. In a laboratory rainfall simulator study, Poesen et al. (1990) concluded that rock fragment position in top soils greatly affects water infiltration. They found that if the rock fragments rested on the top soil, water intake increased and runoff decreased. If the rock fragments were embedded in the top soil, however, infiltration rates were reduced and runoff generation was increased. Such a theory could help to explain the positive correlation we found.

The fact that 3 of the model terms in Eq. 13 are ground cover characteristics and that they represent the distribution of those characteristics as a percentage of either interspace and undercanopy area suggests the importance of considering areas underneath and outside plant canopy independently. In semiarid areas, infiltration and erosion rates are a complex function of plant, soil, and storm characteristics (Gifford 1984). Although infiltration is a soil driven process, vegetation influences are great. Spatial veg- etation characteristics such as root density may act as surrogates for soil characteristics such as bulk density and organic matter. Many studies have shown that the spatial distribution and the amount and type of ground cover are important factors influencing both spatial and temporal variations in infiltration and interrill erosion rates on rangelands (Blackburn et al. 1992, Dunne et al. 1991, Knight et al. 1984, Thurow et al. 1986). In considering $K_{e}$, intended to evaluate hydraulic conductivity for an entire plot, the apparent importance of ground cover on its prediction is not surprising. Given the variability in microtopography within many of these plots, the interception of flow by ground cover could have a potentially large impact on infiltration.

It is important to point out that the new predictive equation was solved for experimental rainfall events with a constant rainfall intensity of $60 \mathrm{~mm} \mathrm{hr}^{-1}$, and therefore a constant $\mathrm{K}_{\mathrm{e}}$ was predicted for each site. In reality, the effective hydraulic conductivity of a hillslope is a nonlinear function of rainfall intensity, initial soil water content, and the distribution and quantity of canopy and ground cover. Lane et al. (1978) reported that significant errors in estimating runoff are possible if it is assumed that a watershed contributes runoff uniformly over the entire area when only a small area within the watershed is actually contributing all of the runoff. Hawkins (1982) observed that the apparent infiltration rate is a nonnegative function of rainfall intensity. The apparent infiltration rate will define the mean areal loss rate only when the maximum infiltration rate has been defined (i.e., when the rainfall intensity equals or exceeds the maximum infiltration rate of any portion of the hillslope or watershed).

The interaction of micro-topography and vegetation on surface storage capacity is one of the major factors that creates confusion between rainfall simulator results and data from natural rainfall induced runoff. For many rangeland areas, rainfall consists of bursts of high rainfall rates followed by reduced rainfall or brief periods of no rainfall followed by intense rainfall rates. During the periods of high intensity rainfall, the surface storage areas overtop and runoff is produced. During periods of lower rainfall intensity, water in surface storage areas infiltrates and must be filled again during the next high rainfall burst. These fluctuations in rainfall intensities contributes to the phenomenon of apparent infiltration rate changing as a function of rainfall intensity (Morin and Kosovsky 1995). In addition, runoff generated in bare interspace areas does not generally flow long distances down slope before being intercepted by vegetation clumps where all or part of the runoff is absorbed depending on the infiltration capacity of the soil. Rainfall simulators with uniform high intensities mask these processes. New research with variable intensity rainfall simulators that can reproduce the natural variability in rainfall intensity are required before rainfall simulator rainfall/runoff results on plots can be accurately related to natural hillslope or watershed runoff responses.

The $\mathrm{K}_{\mathrm{e}}$ values predicted by both the Rawls (Eq. 6) and Risse (Eqs. 9-11) equations are plotted against corresponding optimized values for each plot (Fig. 3a). Both seriously underpredicted $\mathrm{K}_{\mathrm{e}}$ for this data set. The Rawls model resulted in a coefficient of determination very close to 0 . A lower limit of $0.07 \mathrm{~mm} \mathrm{hr}^{-1}$ was set for $\mathrm{K}_{\mathrm{e}}$ in versions of the WEPP model that used the Rawls equations to eliminate the physically impossible case of a negative $\mathrm{K}_{\mathrm{e}}$. Model predicted $\mathrm{K}_{\mathrm{e}}$ defaulted to this minimum value for all of the rangeland plots in this study. The Risse equations showed little improvement, resulting in a coefficient of determination of 0.22 . 
The estimation of $\mathrm{K}_{\mathrm{e}}$ improved when Eq. 13 was tested with the plot data used throughout this study (Fig. 3b), although there is still a bias in underpredicting $\mathrm{K}_{\mathrm{e}}$. Use of this equation results in an $r^{2}$ of 0.60 . The observed value of the $F$ statistic used to test the appropriateness of the linear regression is 14.84 with an associated $p>0.0001$. Each of the 4 terms in the equation are individually significant at the $95 \%$ confidence level.

Figs. $3 \mathrm{c}$ and $3 \mathrm{~d}$ show runoff volume predicted by the WEPP model using the Rawls (Eq. 6) and Risse (Eqs. 9-11) equations plotted against observed runoff volume and the new equation (Eq. 13) plotted against observed runoff volume, respectively. As expected, runoff volume predicted using the new $\mathrm{K}_{\mathrm{e}}$ equation showed improvement over that predicted by the Rawls and Risse equations since the same data set that was used to develop the new equation was also used to test it. Independent rangeland data sets must now be used to test Eq. 13.

\section{Conclusions}

The Green-Ampt equation is sensitive to the effective hydraulic conductivity parameter; therefore, its accurate estimation is (a)

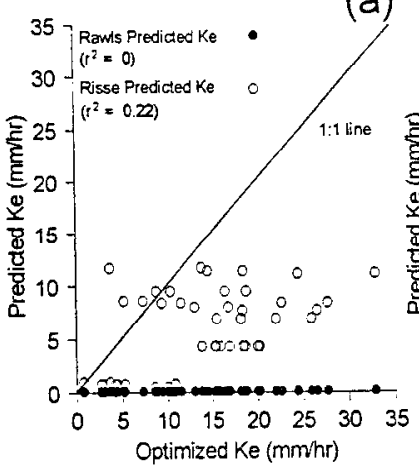

(c)

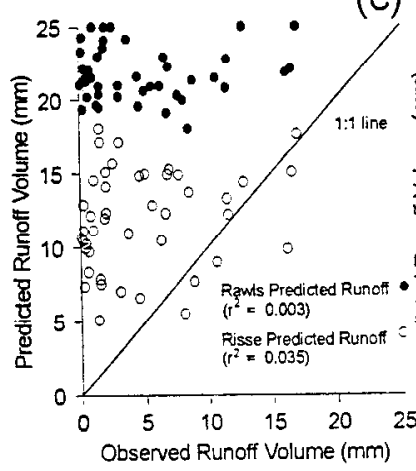

(b)

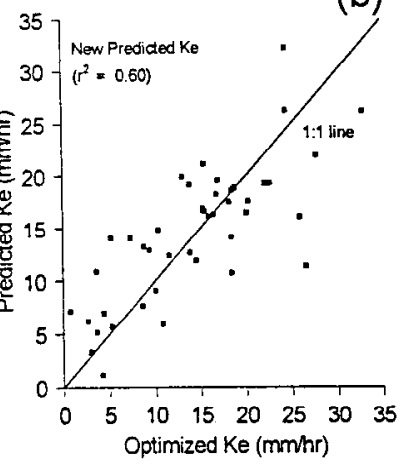

(d)

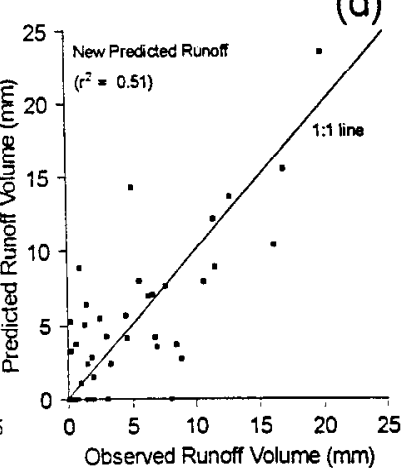

Fig. 3. (a) Observed vs. predicted values of effective hydraulic conductivity $\left(K_{e}\right)$ using algorithms developed by Rawls et al. (1989) and Risse et al. (1993); (b) Observed vs. predicted values of effective hydraulic conductivity $\left(K_{\mathrm{e}}\right)$ using new algorithm developed in this research; (c) Observed vs. predicted runoff volume generated with WEPP using predictive $K_{e}$ algorithms developed by Rawls et al. (1989) and Risse et al. (1993); (d) Observed vs. predicted runoff volume generated with WEPP using predictive $K_{e}$ algorithm developed in this research. important to model results. The algorithms developed by Rawls et al. (1989) and Risse et al. (1995) to calculate effective hydraulic conductivity using data collected from agricultural systems were found to be unsatisfactory for rangeland systems. Using either set of equations, the hydrologic component of WEPP is unable to accurately predict runoff volume.

Although natural systems are complex, adding increasing complexity to physically based models doesn't always improve model predictions (Beven 1989). Sometimes it is better to use simpler regression equations based on interactions of physical characteristics. Such was the logic used to develop the predictive equation presented in this paper. The regression model is well balanced in that it contains a term representing soil texture (clay) and 3 terms representing the distribution of ground cover (litter and basal cover in interspace and rock cover in under-canopy areas). This lends credence to the idea that the spatial distribution of ground cover is an important factor in hydrologic modeling. The equation presented here is recommended for further testing under rangeland conditions for the purpose of independent validation. Further testing is also required to determine its robustness under a broader range of soil and vegetative conditions.

Equation 13 may not be suitable over a continuum of rainfall events with different intensities. Development of the equation was based on the assumption that all other model inputs are correct and model formulation of the effective capillary pressure head at the wetting front in correct. The approach taken herein evaluates spatial variation in cover across the slope, but not down the slope. More work is required to evaluate down slope processes such as flow path continuity and tortuosity.

Finally, the equation was fitted over a relatively large area (35 $\mathrm{m}^{2}$ ) in an attempt to incorporate the spatial variaion of the area into 1 value. There is still a need to define spatial variability of infiltration and runoff along a hillslope, considering also the cumulative total runoff volume at the end of the hillslope using new research methodologies and techniques.

\section{Literature Cited}

Abrahams, A.D. and A.J. Parsons. 1991. Relation between infiltration and stone cover on a semiarid hillslope, southern Arizona. J. Hydrology. 122:49-59.

Beven, K. 1989. Changing ideas in hydrology - the case of physically based models. J. Hydrology. 105:157-172.

Blackburn, W.H. 1975. Factors influencing infiltration and sediment production of semiarid rangelands in Nevada Water Resour. Res. 11:929-937.

Blackburn, W.H., F.B. Piersun, C.L. Hanson, T.L. Thurow, and A.L. Hanson. 1992. The spatial and temporal influence of vegetation on surface soil factors in semiarid rangelands. Trans. ASAE. 35:479-486.

Brakensiek, D.L. and Onstad, C.A. 1977. Parameter estimation of the Green and Ampt infiltration equation. Water Resour. Res. 13:1009-1012.

Brakensiek, D.L. and W.J. Rawls. 1983. Agricultural management effects on soil water processes. Part II. Green and Ampt parameters for crusting soils. Trans. ASAE. 26:1753-1757.

Brakensiek, D.L., W.J. Rawls, and G.R. Stephenson. 1986. Determining the saturated hydraulic conductivity of a soil containing rock fragments. Soil Sci. Soc. Amer. J. 50:834-835.

Chu, S.T. 1978. Infiltration during steady and unsteady rain. Water Resour. Res. 14:461-466. 
Cooke, R.V. and A. Warren. 1973. Geomorphology in deserts. Univ. Calif. Prcss, Bcrkclcy, Calif.

Dadkhah, M. and G.F. Gifford. 1980. Influence of vegetation, rock cover, and trampling on infiltration and sediment production. Water Res. Bull., Amer. Water Res. Assoc. 16:979-986.

Dunne, T., W. Zhang, and B.F. Aubry. 1991. Effects of rainfall, vegetation, and microtopography on infiltration and runoff. Water Resour. Res. 27:2271-2285.

Gifford, G.F. 1984. Vegetation allocation for meeting site requirements, p. 35-116. In: NAS/NRC. Developing Strategies for Rangeland Management. Westview Press.

Gould, F.W. 1975. The grasses of Texas. Texas A\&M University Press, College Station, Tex.

Green, W.H. and G.A. Ampt. 1911. Studies on Soil Physics: 1. Flow of air and water through soils. J. Agr. Sci.. 4:1-24.

Hanson, C.L., A.R. Kuhlman, and J.K. Lewis. 1978. Effect of grazing intensity and range condition on hydrology of western South Dakota ranges. South Dakota Agr. Exp. Sta. Bull. 647, 54 p.

Haupt, H.F. 1967. Infiltration, overland flow, and soil movement on frozen and snow-covered plots. Water Resour. Res. 3:145-161.

Hawkins, R.H. 1982. Interpretations of source area variability in rainfall-runoff relations, p. 303-324. In: V.P. Singh (ed.), Rainfall-runoff relationships. Water Resources Pub.

Hillel, D. 1980. Fundamentals of Soil Physics. Acad. Press, New York, N.Y.

Kahn, M.J., E.J. Monke, and G. R. Foster. 1988. Mulch cover and canopy effect on soil loss. Trans. ASAE. 31:706-711.

Klute, A. and C. Dirksen. 1986. Hydraulic conductivity and diffusivity: labortory methods, p. 687-734. In: A. Klute (ed.), Methods of soil analysis, part 1. Amer. Soc. Agron., Madison, Wisc.

Knight, R.W., W.H. Blackburn, and L.B. Merrill. 1984. Characteristics of oak mottes, Edwards Plateau, Texas. J. Range Manage. 37:534-537.

Lane, L.J. and M.A. Nearing (eds). 1989. USDA-Water Erosion Prediction Project: Hillslope Profile Model Documentation. NSERL Report No. 2. West Lafayette, Ind: USDA-ARS-Natl. Soil Erosion Research Lab.

Lane, L.J., M.H. Diskin, D.E. Wallace, and R.M. Dixon. 1978. Partial area response on small semiarid watersheds. Water Resour. Bull. $14: 1143-1158$.

Lane, L.J., J.R. Simanton, T.E. Hakonson, and E.M. Romney. 1987. Large-plot infiltration studies in desert and semiarid rangeland areas of the southwestern USA, p. 365-377. In: Proc. Int. Conf. on Infiltration Devt. and Application. Univ. of Hawaii, Honolulu.

Mein, R.G and C.L. Larson. 1973. Modeling infiltration during a steady rain. Water Resourc. Res. 9:384-394.

Meyer, L.D., W.H. Wischmeier, and G.R. Foster. 1970. Mulch rates required for erosion control on steep slopes. Soil Sci. Soc. Amer. Proc. 34:982-991.

Moore, I.D. 1981. Effect of surface sealing on infiltration. Trans. ASAE. 24:1546-1561

Morin, J. and A. Kosovsky. 1995. The surface infiltration model. J. Soil and Water Cons. 50:470-476.

Packer, P.E. 1951. An approach to watershed protection criteria. J. Forest.. 49:639-644.

Poesen, J., F. Ingelmn-Sanchez, and H. Mucher. 1990. The hydrological response of soil surfaces to rainfall as affected by cover and position of rock fragments in the top layer. Earth Surfaces and Landforms. 15:653-671.

Rauzi, F., C.L. Fly, and E.J. Dyksterhuis. 1968. Water intake on midcontinental ranglands as influenced by soil and plant cover. USDA Tech. Bull. No. 1390.

Rawls, W.J. and D.L. Brakensiek. 1983. A procedure to predict Green and Ampt infiltration parameters, p. 102-112. In: Proc. of the Amcr. Soc. of Ag. Eng. Conf. on Advan. in Infiltration, Chicago, Ill.

Rawls, W.J. and D.L. Brakensiek. 1985. Prediction of soil water properties for hydrologic modeling, p. 239-299. In: E.B. Jones and T.J. Ward (eds.). Watershed Management in the Eighties. Proc. of Symp. sponsored by Comm. on Watershed Management, I \& D Division, ASCE, Denver, Colo.
Rawls, W.J. and D.L. Brakensiek. 1989. Estimation of soil water retention and hydraulic properties, p. 275-300. In: Unsaturated flow in hydrologic modeling: theory and practice, Kluwer Academic Publishers, Boston, Mass.

Rawls, W.J. and D.L. Brakensiek, and K.E. Saxton. 1982. Estimation of soil water properties. Tran ASAE. 25:1316-1320

Rawls, W.J., J.J. Stone, and D.L. Brakensiek. 1989. Chapter 4; Infiltration. In: L.J. I.ane and M.A. Nearing (eds.), Profile Model Documention. USDA-Water Erosion Prediction Project: Hillslope Profile Version. NSERL Report No. 2, USDA-ARS, National Soil Erosion Research Lab., W, Lafayette, Ind.

Risse, L.M., Liu, B.Y., and M.A. Nearing. 1995. Using curve numbers to determine baseline values of Green-Ampt effective conductivities. Water Resour. Bull. 31:147-158.

SAS Institute Inc. 1985. SAS/STATTM Guide for Personal Computers, Version 6 Edition. Cary, N.C.: SAS Institute Inc.

Savabi, M.R., W.J. Rawls, and R.W. Knight. 1995. Water Erosion Prediction Project (WEPP) rangeland hydrology component evaluation on a Texas rangesite. J. Range Manage. 48:535-541.

Shiflet, T.N. 1994. Rangeland cover types of the United States, Society for Range Management, Denver, Colo.

Simanton, J.R., E. Rawitz, and E.D. Shirley. 1984. Effects of rock fragments on erosion of semiarid rangeland soils. Soil Sci. Soc. Am. Spec. Publ. 13:65-72.

Simanton, J.R., M.A. Weltz, and H.D. Larsen. 1991. Rangeland experiments to parameterize the water erosion prediction project mode: vegetation canopy cover effects. J. Range Manage. 44:276-282.

Simanton, J.R., L.T. West, M.A. Weltz, and G.D. Wingate. 1987. Rangeland experiments for water erosion prediction project. ASAE Paper No. 87-2545.

Singer, M.J., Y. Matsuda, and J. Blackard. 1981. Effects of mulch rate on soil loss by raindrop splash. Soil Sci. Soc. Am. J. 45:107-110.

Swanson, N.P. 1965. Rotating-boom rainfall simulator. Trans. ASAE 8:71-72.

Thomas, G.W., and V.A. Young. 1954. Relation of soils, rainfall, and grazing management to vegetation, western Edwards Plateau of Texas. Texas Agr. Exp. Sta. Bull. 786.

Thurow, T.L., W.H. Blackburn, and C.A. Taylor, Jr. 1986. Hydrologic characteristics of vegetation types as affected by livestock grazing systems, Edwards Plateau, Texas. J. Range Manage. 39:505-509.

Tiscareno-Lopez, M., V.L. Lopez, J.J. Stone, and L.J. Lane. 1993. Sensitivity analysis of the WEPP watershed model for rangeland applications I: Hillslope processes. Trans. ASAE. 36:1659-1672.

Tromble, J.M., K.G. Renard, and A.P. Thatcher. 1974. Infiltration for three rangeland soil vegetation complexes. J. Range Manage. 27:318-321.

USDA, National Resources Conservation Sevice. 1995. National Handbook for Grazing land Ecology and Management. National Headquarters, Washington, D.C. (in press)

Weaver, J.E. and G.W. Harmon. 1935. Quantity of living plant materials in prairie soils in relation to run-off and soil erosion. Bull. 8: Cons. Dept. of the Cons. and Survey Div. Univ. of Neb.

Weltz, M.A. and M.K. Wood. 1986. Short duration grazing in central New Mexico: effects on infiltration rates. J. Range Manage. 39:365-368.

Wilcox, B.P., M.K. Wood, and J.M. Tromble. 1988. Factors influencing infiltrability of semiarid mountain slopes. J. Range Manage. 41:197-206.

Wilcox, B.P., M. Sbaa, W.H. Blackburn, and J.H. Milligan. 1992. Runoff prediction from sagebrush rangelands using water erosion prediction project (WEPP) technology. J. Range Manage. 45:470-474.

Wood, M.K. and W.H. Blackburn. 1981. Grazing systems: their influence on infiltration rates in the Rolling Plains of Texas. J. Range Manage. 34:331-335. 